\title{
History and Challenges of U.S. Immigration Policymaking
}

\author{
Kira Haensel \\ Florida International University \\ Florida, United States \\ Jean-Claude Garcia-Zamor (Corresponding author) \\ Florida International University \\ Florida, United States \\ Email: garciazamor@hotmail.com
}

Received: November 28, 2016 Accepted: December 17, 2016 Published: December 31, 2016 doi:10.5296/jpag.v6i4.10621 URL: http://dx.doi.org/10.5296/jpag.v6i4.10621

\begin{abstract}
This article reviews the history of immigration policy in the U.S. and discusses different domestic measures that benefited the country's economy. It examines the current controversy created by the presence of large number of illegal immigrants. It provides a brief overview of the development of U.S. immigration policy, pointing out events that led to a change in the said policies and to the restrictive measures adopted. It addresses the question of how the borders can be controlled and looks at previously implemented strategies and their outcomes as well as their sometimes unforeseen consequences. The article furthermore addresses the question of what effects immigration has on the U.S. and who profits from it. Finally, in this article, the battle over immigration policy in congress is discussed. The point made is that the reason for the slow progress in immigration policy is the lack of consensus in congress for a coherent immigration policy.
\end{abstract}

Keywords: Immigration policy, Borders control, Immigration benefits, Congress inaction. 


\section{Introduction}

The United States of America, often described as a nation of immigrants, has a history of immigration policy that reaches back several centuries. The country went through different phases of welcoming and even being in need of immigrants and their labor, to drastically restricting immigration. The following article provides a brief overview of the development of U.S. immigration policy, pointing out events that led to a change in the said policies and to the restrictive measures adopted.

The focus then lies on one of the most discussed subjects, not only by policy makers, but by the media, the population and the presidential candidates in the 2016 elections. This subject addresses the question how to secure the borders. By borders it is usually referred to the Southern border with Mexico, the border many politicians and a large proportion of the U.S. population is most eager to completely control. This task however has proven to be a difficult one. The second part of this article thus deals with the question if borders can be controlled and for this purpose looks at previously implemented strategies and their outcomes as well as their sometimes unforeseen consequences.

The article furthermore addresses the question what effects immigration has on the U.S. and who profits from it. Contrary to the widely spread assumption that immigration mainly entails negative consequences for the recipient county, this research finds that the U.S. as a recipient country benefits vastly from immigration and even relies on it to some extent.

Finally, in this article, the battle over immigration policy in congress is discussed. The point made is that the reason for the slow progress in immigration policy is the disunity in congress between Senate and House of Representatives.

\section{History of Immigration Policy in the U.S.}

Restrictions on immigration in the US reach back to the late $19^{\text {th }}$ century when the congress voted on immigration laws such as the literacy requirement for immigrants and the exclusion of convicts and prostitutes with $85 \%$ in favor. Before that, due to political and economic circumstances as for instance the discovery of gold and the industrialization process, the United States (US) were eager to attract migrants to work in farms and factories. Between 1820 and 1840 approximately 2.8 million Irish immigrated to the US, (Solimano, 2010). In the twentieth century, the main heritage countries of migrants shifted from European countries to Latin American and to a lesser extend Asian countries.(White, 2015, p. 94).

World War I eventually changed international travel and migration substantially, also affecting immigration policies in the US. "[...] military and security restrictions on travel and migration during World War I ushered in a world of passports, visas and work permits governing international migration" (Solimano, 2010, p. 6).

Throughout the $20^{\text {th }}$ century numerous national immigration restrictions were added, marking the evolution of a quite strict immigration policy (Aghion \& Williamson, 1998). The terror attack in September 2001 then changed the debate on border protection significantly. Borders should now not only be protected against illegal immigration that impacts US economy and 


\section{Macrothink Institute ${ }^{T M}$}

culture, but against persons who come with the intention to do harm.(Brown \& Rodriguez, 2014). "Whereas previously, the purpose of a secure border was to control and limit the entry of undocumented immigrants, now it was meant to stop terrorists; the urgency to secure the border and to do so comprehensively was heightened proportionately." (Brown \& Rodriguez, 2014, p. 108).

As a result, the rhetoric of immigration policy changed, connecting immigration to terrorism and border security. One example for this is the affiliation of the Immigration and Naturalization Service's into the Department of Homeland Security created in 2002, combining 22 agencies, including Customs and Border Protection, Citizenship and Immigration Services, and Immigration and Customs Enforcement, (ibid.).The Department of Homeland Security as of today deploys 240,000 people, constituting the third largest U.S. Department, (Department of Homeland Security, 2016). In 2016, the Department deployed another 2,000 U.S. Customs and Border Protection (CPB) Officers which sum up to a total of 21,370 Border Patrol agents and 23,871 CBP officers (DHS, 2016). The provision of more staff was made possible by a budget increase of over 4.5 Million US Dollars over the last two years.

\section{Figure 1}

Number of Border Patrol Agents Rose Dramatically

Most work along the southwestern border

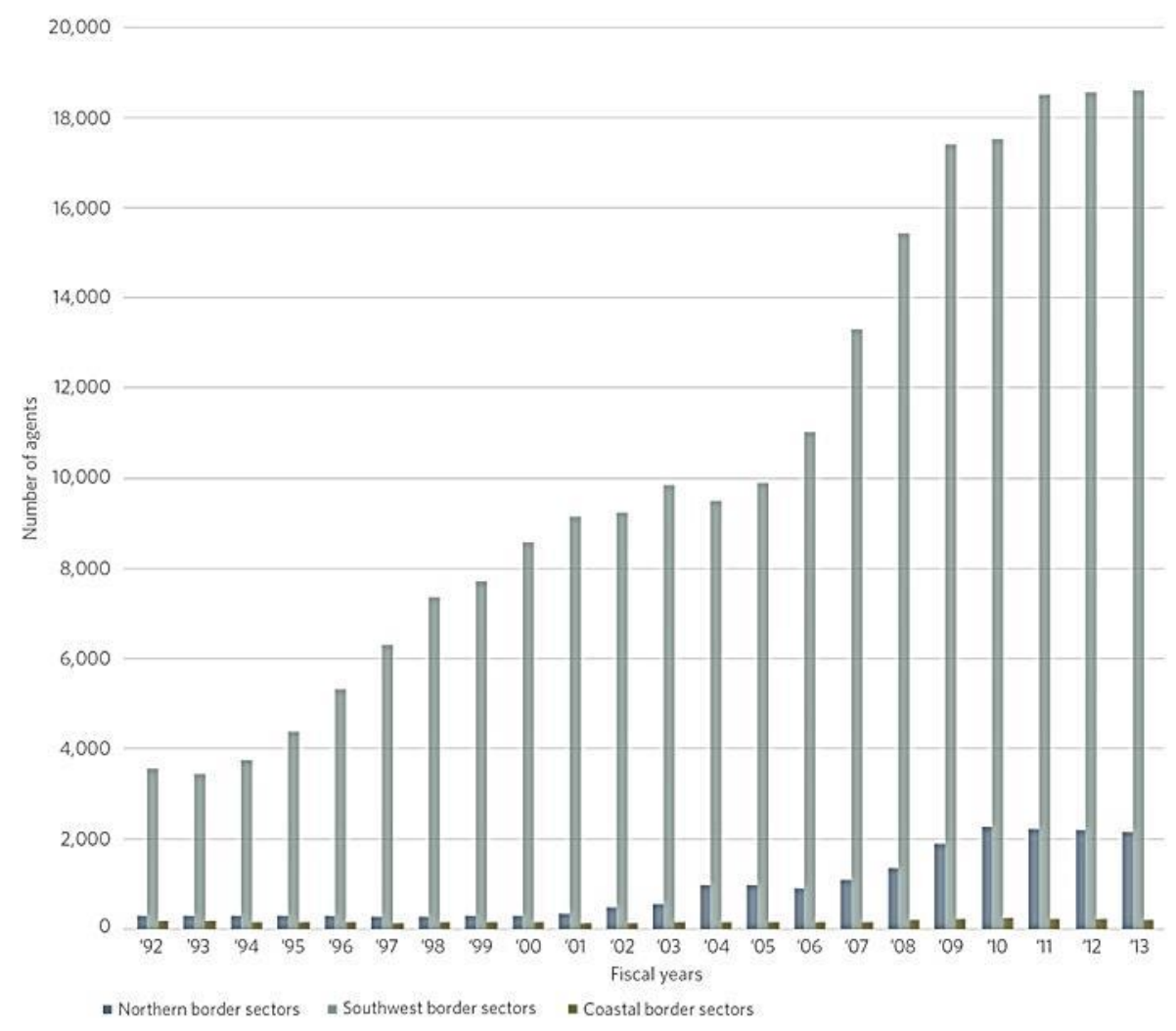

Source: U.S. Customs and Border Protection, "Nationwide Staffing 1992-2013" (Sept. 30, 2013)

(c) 2015 The Pew Charitable Trusts

Another consequence of 9/11 in terms of immigration policy was the USA Patriot Act, which 
"broadens the terrorism grounds for excluding aliens from entering the Unites States and increases monitoring for foreign students." (Migration Policy Institute, 2013). The terrorist attacks form 2001 showed that the way the terrorists had entered the country was not through immigration, but through tourist, business and student visas. Thus, "from a border security standpoint, it is the increasing numbers of international travelers that present a challenge to border-control officials attempting to identify dangerous or unauthorized individuals within such growing travel flows" (Koslowski, 2011, p. 5). As a consequence, additional to the staff increase, significant parts of the budget increase were dedicated to control supporting technologies such as the US-VISIT's Biometric Identification and Analysis Services, which collect biometric information from every traveler to the US, (DHS, 2008).

Also in 2016, large parts of DHS budget were spent on technologic advancements such as the Electronic Visa Information Update System (EVIUS) and the National Protection and Programs Directorate Replacement Biometric System. The latter reduces operating costs, improves detection capabilities and the process efficiency of Biometric Services, while EVIUS facilitates pre-travel risk determinations.(DHS, 2016). However, critics argue that these technologies lack reliable functionality and that the immense costs are thus disproportionate to the benefit. This will be further discussed under the next section "Can the U.S. border be controlled?".

A legislative document worthwhile mentioning also in conjunction with this year's Presidential election is the Secure Fence Act of 2006. The bill signed by former U.S. President George W. Bushhad the goal to construct a 700 mile fence along the southern US border with Mexico. Until today, the construction of the fence has not been finished. The objective of the fence is to decrease illegal entry, security threats and drug trafficking. Yet, opinions differ on whether the fence has fulfilled its purpose. Even though numbers of detected illegal border crossing decreased after parts of the fence were constructed, the Congressional Research Service found "strong indication" that people who illegally crossed the border simply found other routes, (Simon, 2009). Furthermore, the construction of the fence was criticized for environmental reasons and the protection of wildlife, (ibid.).

Today, US immigration policy is built on four core principles, which are (1) family reunification, (2) the admission of immigrants with occupational skills in demand, (3) the protection of refugees, and (4) the diversity of immigrants by country of origin (Wasem, 2004). In total, 675,000 Green Cards, which grant lawful permanent residence status to the applicant, are yearly issued in the US. The majority of these cards go to applicants who are family sponsored, meaning that a family member is already legally living in the US; "Family reunification is the primary consideration for legal migration" (White, 2015, p. 94). The second largest group of Green Card recipients is immigrants with occupational skills in demand, followed by diversity immigrants who are coming from countries that have low immigration rates in the US, (ibid.).

\section{Can the U.S Borders be Controlled?}

The control of US borders has become one of the major challenges for the US government over the past decades. "Faced with enormous political pressure to stop illegal immigration 
and to prevent the entry of potential terrorists, the U.S. government has devoted ever more resources to enforcing border policies." (Koslowski, 2011). However, it remains unclear how efficient these policies are, especially considering their immense costs, (ibid.).

As said before, the main entry point and thus the border the US is most eager to control is the US-Mexico border. Besides from Mexicans entering through the southern border, "There is also significant migration of Central Americans through Mexico en route to the United States, which has resulted in US pressure on Mexico to strengthen its southern border, and multilateral efforts among several countries in the region." (White, 2015, p. 97). Efforts to protect the US border with Mexico include the construction of a fence, the installation of radars and ground sensors and the increased deployment of border patrol agents. As mentioned before, the effectiveness of a fence as a means to prevent illegal migrants from entering the country is highly controversial and strong indication exists that people simply find different ways to enter.

In 2012, the U.S. Department of Homeland Security introduced a risk-based strategic plan, the 2012-2016 Border Patrol Strategic Plan, in order to manage border protection. The plan introduces strategic border protection goals and corresponding measures to be undertaken by the department and its personnel. The two goals are (1) to secure America's borders, and (2) to strengthen the border patrol. Measures to achieve these goals include "methods of detecting illegal entries such as using "change detection" techniques [periodic UAS over flights, sign-cutting, used to gather information and intelligence in low-threat areas], increased mobile-response capabilities, and expanded use of specially trained personnel with "force multiplying" skills and abilities", (U.S. Customs and Border Protection, 2012, p. 8).

The 2012-2016 is the third plan of this type introduced by the agency. The 2004 plan's goal was "operational control". Critics stated that the 2004 plan did not achieve its goal, which is why the 2012-2016 plans consist of new goals and measures. Data ascertained by the Government Accountability Office (GAO) in 2012 show that only 61 percent of people crossing the border illegally are noticed, and that only 44 percent of the border was under "operational control", which, as said before, constituted the goal of the 2004 plan. House Homeland Security Committee Chairman Michael McCaul commented on the issue that "The bottom line is that we are far from having operational control of our borders" (The Week, 2013).

All of the new technologies mentioned earlier face complications in terms of implementation. The US-VISIT's system is a system that is particularly difficult to properly implement, since it requires comprehensive data collection of entry as well as exit data. In order to collect exit data corresponding to every entry, large investments in border infrastructure that exceed the extensive budgets dedicated to security technology throughout the last years would have to be made. While one of the main criticisms of the system is the still missing collection of exit data, which would for example enable the detection of visa overstays, "technology implementation difficulties have raised questions whether there might be better ways to spend resources in the efforts to reduce illegal immigration" (Koslowski, 2011, p. 20).

In 2016, maybe more than ever, the question of immigration is one of the most controversial 
topics in the United States, with many people being unsatisfied with the situation. The last two presidents, George W. Bush and Barack Obama, were unable to "forge an effective immigration policy with bipartisan congressional support" (White, 2015, p. 93). This has to do on the one hand with the immense influx of migrants; Aside from the European Refugee crisis that occurred in the context of the ongoing war in Syria, the United States are the country that is challenged most by immigration, due to its leading position in immigration numbers. More than one out of five migrants in the world resides in the US, (ibid.).

On the other hand, difficulties arise with the various players involved. Solimano lists the following as involved players and their interests: "companies that need migrant labor to moderate wages and enhance profit margins; labor unions that see immigrants as competing for jobs and potentially displacing local workers (although other unions can be pro-immigration, perceiving that immigrants will take jobs that Americans do not want anymore, and that they are a new group of labor that can be organized and mobilized); conservative groups that are afraid of the cultural consequences of massive immigration for national identity and sovereignty; public opinion that tilts between pro and con; and policymakers and politicians who are concerned about the pressures of immigration on the costs of housing and public finances and its impact on voters. Still another important actor is, of course, the immigrant community itself - its economic interests, legal status, and social demands." (Solimano, 2010, pp. 8,9).

As the Presidential election 2016 has shown, border management remains one of the topics that receives the most political attention. Yet, the varying success of the measures taken makes it questionable whether support for these programs should be continued or if a change in strategy would lead to greater success. The issue of ineffective immigration policy and the connection to discrepancies in congress is further addressed under point 4 "The Battle in Congress over Policies".

In terms of change in strategy, the possibly negative consequences of increased border security should be considered as well. One of these is connected to seasonal work. For instance, many illegal immigrants with Mexican heritage are not permanently residing in the U.S. These people usually have families in Mexico and travel to the U.S. to work in a seasonal job such as for instance harvesting and then return home to Mexico. Increased border security could prevent illegal seasonal workers from returning to Mexico and make them decide to stay permanently, possibly with their families, in order to avoid getting caught while crossing the border. Hollifield et al. explain that "The efforts to reduce the influx of unauthorized migrants entering via Mexico have not reduced the stock of such immigrants; instead, they have produced a more stable, settled population." (Hollifield, Martin, \& Orrenius, Controlling Immigration, 2014, p. 10).

On the other hand, it could prevent people from returning to the U.S. for seasonal work, which could affect the U.S. economy, since there is a high demand for seasonal workers in agriculture, and service; usually low-wage labor. One possible solution to handle this issue would be to provide temporary work visas which would allow people to be deployed for seasonal jobs, (The Week, 2013); (Hollifield, Martin, \& Orrenius, Controlling Immigration, 
2014).

Furthermore, additional border security could spur the smuggling industry led by Mexican gangs and cartels. In order to get transported across the border, people have to pay up to $\$ 30,000$. Attempts to illegally cross the border solo are risky, due to the control of the cartels. According to the U.S. Immigration and Naturalization Service, approximately 90 percent of illegal immigrants pay smugglers in order to cross the border, (The Week, 2013).

Another consequence that is usually left out of policy discussions are the many lives the border claims. Due to increased border security, illegal immigrants find themselves in extremely hazardous situations trying to cross the border in dangerous and isolated places.

What we've seen is that the death rate has gone up even though the number of people crossing has gone down, the direct result of more agents, more fencing, and more equipment. The migrants are walking in more treacherous terrain for longer periods of time, and you should expect more deaths. [...] So they're going around the fences, the technology and where the agents are. And the farther you walk from a safe place, the more likely a broken ankle becomes a death sentence. [...] In 2009, an analysis of bodies recovered in the deadliest section of the border found that the risk of dying was 1.5 times higher in 2009 than in 2004 and 17 times greater than in 1998.(Jimenez, 2009, pp. 8,10); (Brown \& Rodriguez, 2014, p. 109).

\section{Who Profit from Immigration?}

Daniel E. Martínez, Assistant Professor of sociology at George Washington University who released a report on the numeric and demographic nature of the deaths of illegal immigrants at the U.S./Mexico border in 2009 commented that "We're missing the point. The answers don't lie in border security. The answers lie in understanding the economics [that drive migration]," (Mello, 2013). One of these economics is the demand for low-wage labor in the U.S.

While the public predominantly reflects a negative perception of immigrants and their impact on the economy, the job market, wages, and culture, empirical evidence that this is not the case gets widely ignored, (Hollifield, Martin, \& Orrenius, Controlling Immigration, 2014).

Quite the contrary, capitalism calls for open borders and diminishing fences in order to facilitate the flow of services, labor and resources and thus the creation of new markets. Furthermore, the Wall Street Journal and the U.S. Chamber of Commerce call on the federal government to realize that increasing border security will affect the economy negatively for one thing that undocumented seasonal workers will be discouraged to return home, and for another that they cover the labor demand predominantly in low-skilled jobs, (Brown \& Rodriguez, 2014). Moreover, the U.S. Chamber of Commerce assessed plans to remove "the 10 to 12 million undocumented individuals in the United States as impractical." (Brown \& Rodriguez, 2014, p. 110). The U.S. Chamber of Commerce as well as the Wall Street Journal recommends either regularizing or naturalizing undocumented populations, (ibid.).This could also be a measure to hold back the downward pressure on wages, since immigrants who fall under this division could work in regular jobs and claim their right to fair pay. 
Others like Riley call for letting the "law of supply and demand work [...]", (Riley, 2008). According to Riley, the vast majority of immigrants coming from Mexico are people who want to work. Creating legal ways for them to be able to work will obviously reduce illegal immigration and, as Riley explains, will give the homeland security the chance to concentrate on real threats. This directly leads to another point, namely the misperception that undocumented immigrants engage more in criminal behavior than the rest of the population, (ibid.).

Another argument that comes up quite frequently when talking about consequences of undocumented immigration is taxes. According to that, some argue that illegal immigrants bypass the tax system and therewith hurt welfare (not that the U.S. is a great welfare state anyway). Yet, in fact 75 percent of undocumented working immigrants are deployed in the formal sector using false documents, such as fake Social Security Numbers in order to get hired. This means they actually do get a tax deduction on their paycheck plus they usually would not claim for tax returns by the end of the fiscal year due to their false documents, which in turn means that they could end up paying even more taxes than a regular employee. Moreover, irregular immigrants would usually not make use of any kind of social security, since according to the Social Security Protection Act of 2004 only regular employees are authorized to receive benefits. Summarizing, only 25 percent of undocumented workers (app. 1.8 million) do not pay taxes, which adds up to a loss of approximately $\$ 2.7$ billion a year. This number might at first sound high; however compared to 195 billion USD in taxes, which are evaded by 25 million U.S. citizens annually due to unreported ancillary revenue, $\$ 2.7$ billion is a small percentage of it. Furthermore, undocumented immigrants like anybody else, pay sales tax on property, groceries and so forth.(Guskin \& Wilson, 2007).

Furthermore, we should not forget that a great percentage of (illegal) immigrants work in low-wage jobs mostly in the agricultural and service sector, since these jobs usually require minimum language skills and only basic education. Generally speaking, these are not jobs that are highly coveted among the population however, there is great demand and someone has to work in these jobs if we want to continue to shop groceries at a competitive price, go out to dine in restaurants, bring our children to daycare, and so forth.

Another point to discuss is remittances. Accordingly, many immigrants send money home to their families. This means that they do not spend a proportion of their money within the U.S. economy. In relation to the size of the U.S. economy, the amounts of money we are talking about here are fairly small. Also, immigrants pay fees to U.S. companies like Western Union in order to send money home. Furthermore, remittances can be considered a form of foreign aid and some portions of it, especially in countries closely tied to the U.S., are spent on goods distributed by the U.S. which means that the money finds its way back either way, (Guskin \& Wilson, 2007).

\section{The Battle in Congress over Policies}

During the 2016 Presidential election, immigration policy was one of the most controversial topics. Donald Trump catered for turmoil with his plan to deport millions of undocumented immigrants and to construct a wall at the US-Mexican border (paid for by the Mexican 
government). A poll conducted by Rasmussen Reports in February 2016 revealed that 51 percent of all voters, and 70 percent of Republican voters support Trump's idea to build a wall. Another poll conducted in March of the same year revealed that while support from Republican voters to construct the wall remained high, support of overall voters declined. However, three out of four voters stated that the issue of illegal immigration is an important one in respect of their vote, (Pulse Opinion Research, 2016).

This means that immigration, as said before, is still one of the most discussed political topics. While many arguments that point to immigration as a negative thing were devitalized in this article, it would be false to say that the dominant public opinion on immigration reflects this. Also in congress we can see that on both ends of the political spectrum it is argued that we need to do something about our "immigration issue". The loudest voices come from the far right, with wordings such as "invasion", "mortal danger" or "state of emergency", (White, 2015, p. 97).

In 2011/2012, the Democratic majority in the Senate proposed an immigration reform that suggested the legalization of undocumented immigrants, yet the Republican controlled House blocked the reform. Another approach in 2013 again failed to lead to a major reform of immigration law due to discrepancies between House and Senate. The Senate approved the proposed Act called Border Security, Economic Opportunity, and Immigration Modernization Act which suggested "more enforcement to deter unauthorized entry and employment, a path to legal immigrant and eventual US citizen status for most of the 11 million unauthorized foreigners in the country, and new and expanded programs to admit more foreign workers." (Hollifield, Martin, \& Orrenius, Controlling Immigration, 2014, p. 60). However, the House of Representatives did not approve the comprehensive approach, but considered some aspects of it that dealt with increased enforcement, (ibid.).

Besides from the inability of the Congress to agree on a major immigration reform, the policies at work do not meet the set expectations. There is a "gap between the goals and results of national immigration policy [that] is growing wider in the major industrial democracies, thus provoking greater public hostility toward immigrants in general (regardless of legal status) and putting pressure on political parties and government officials to adopt more restrictive policies" (Hollifield, Martin, \& Orrenius, Controlling Immigration, 2014, p. $3)$.

\section{Conclusion}

Summarizing, it can be said that the demand for higher security as well as economic circumstances have led to implementation of restrictive migration policies in the U.S., a country that once was eager for people to immigrate. One of the main concerns is to control the Southern border to Mexico and to protect the country from terrorism, wherefore different policies with the goal to control and restrict migration were implemented throughout the last years. However, the "migration problem" remains on the top of the political agenda in the U.S., indicating that undertaken measures lack sufficiency and that the control of the borders is a goal yet to achieved. 


\section{MInstitute Macrothink $^{\text {Int }}$}

Journal of Public Administration and Governance

ISSN 2161-7104

On the other hand the article suggests a change of thinking regarding the immigrant question and the impacts (illegal) immigrants have on U.S. economy and culture. What becomes clear is that there is a discrepancy between the predominant public perception of immigrants and their impacts on different aspects, such as for instance the economy, the recommendations by the Chamber of Commerce and others from a capitalist viewpoint, and numbers recorded (e.g. fatalities, violence, etc.). This should give rise to reconsider the dialogue concerning immigration policy making, since not all aspects seem to be covered, such as the negative consequences of increased border security and false assumption that immigration, even if it is irregular, impacts the country negatively in economic terms.

\section{References}

Aghion, P., \& Williamson, J. G, (1998). Growth, Inequality, and Globalization: Theory, History, and Policy. New York: Cambridge University Press.

Brown, D., \& Rodriguez, A, (2014). When Race and Policy Collide - Contemporary Immigration Debates. Santa Barbara : ABC-CLIO.

Deparment of Homeland Security, (2016, June 29). Department of Homeland Security. Retrieved November 10, 2016, from https://www.dhs.gov/about-dhs

DHS, (2008). DHS. Retrieved November 14, 2016, from https://www.dhs.gov/xlibrary/assets/usvisit/usvisit_edu_biometrics_brochure_english.pdf

DHS, (2016). Budget-in-Brief. Retrieved November 14, 2016, from https://www.dhs.gov/sites/default/files/publications/FY_2016_DHS_Budget_in_Brief.pdf

Guskin, J., \& Wilson, D. L, (2007). Are Immigrants hurting our Economy? In The Politics of Immigration: Questions and Answers (pp. 63-72). New York: NYU Press.

Hollifield, J. F., Martin, P. L., \& Orrenius, P. m, (2014). Controlling Immigration. Stanford: Stanford University Press.

Hollifield, J. F., Martin, P. L., \& Orrenius, P. M, (2014). Controlling Immigration. Stanford University Press: Stanford University Press.

Jimenez, M, (2009, October 1). American Civil Liberties Union. Retrieved November 22, 2016, from https://www.aclu.org/files/pdfs/immigrants/humanitariancrisisreport.pdf

Koslowski, R, (2011, February). Migrationpolicy. Retrieved November 1, 2016, from http://www.migrationpolicy.org/research/evolution-US-border-controls-illegal-immigration

Mello, M, (2013, June 13). Huffington Post. Retrieved November 22, 2016, from http://www.huffingtonpost.com/2013/06/13/border-security-boost-led_n_3436293.html

Migration Policy Institute, (2013, March). Migration Policy Institute. Retrieved November 09, 2016, from http://www.migrationpolicy.org/research/timeline-1790

Pulse Opinion Research, (2016, April 06). Rasmussen Reports. Retrieved November 9, 2016, 
from

http://www.rasmussenreports.com/public_content/politics/current_events/immigration/april_2 016/gop_voters_still_favor_border_wall_other_voters_less_so

Riley, J, (2008). Let Them In: The Case for Open Borders. Nelson A. Rockefeller Insitute of Government.

Simon, S, (2009, February 04). Border-Fence Project Hits a Snag. Retrieved November 09, 2016, from The Wall Street Journal : http://www.wsj.com/articles/SB123370523066745559

Solimano, A, (2010). International Migration in the Age of Crisis and Globalization. New York: Cambridge University Press.

The Week, (2013, March 16). The Week. Retrieved November 10, 2016, from http://theweek.com/articles/466628/what-take-secure-usmexico-border

U.S. Customs and Border Protection, (2012). U.S. Customs and Border Protection. Retrieved November $\quad 10, \quad 2016, \quad$ from https://www.cbp.gov/sites/default/files/documents/bp_strategic_plan.pdf

Wasem, R, (2004). U.S. immigration policy on permanent admissions. Washington, D.C.: Congressional Research Services.

White, C, (2015 ). Immigration and Regional Integration In a Globalizing World: Myths and Thruths about Migration . Lanham, Maryland: Lexington Books.

\section{Copyright Disclaimer}

Copyright for this article is retained by the author(s), with first publication rights granted to the journal.

This is an open-access article distributed under the terms and conditions of the Creative Commons Attribution license (http://creativecommons.org/licenses/by/3.0/). 